\title{
Wykorzystanie komponentów biogennych do wytwarzania paliw pozostałościowych
}

\section{The use of biogenic components for the production of residual fuels}

\author{
Anna Duda \\ Instytut Nafty i Gazu - Państwowy Instytut Badawczy
}

\begin{abstract}
STRESZCZENIE: W niniejszej publikacji przeprowadzono badania wpływu komponentów biogennych na jakość paliw pozostałościowych. Zastosowanie komponentów biogennych do wytwarzania paliw pozostałościowych umożliwiłoby uzyskanie paliw żeglugowych oraz ciężkiego oleju opałowego o poprawionych walorach ekologicznych, tj. o niższej zawartości siarki oraz mniejszej emisji GHG (greenhouse gas). Badania prowadzono dla jednego rodzaju bazowego paliwa ciężkiego oraz dwóch komponentów lekkich: FAME (fatty acid methyl ester) i biowęglowodorów z procesu ETG (ethanol to gasoline). Zakres destylacji komponentu z procesu ETG mieścił się $\mathrm{w}$ przedziale od $172^{\circ} \mathrm{C}$ do około $318^{\circ} \mathrm{C}$. Był on produktem stabilnym, o charakterze aromatycznym, bardzo niskiej temperaturze płynięcia i śladowej zawartości siarki. Komponent FAME charakteryzował się jakością typową dla tego typu komponentu z wyjątkiem stabilności oksydacyjnej. Komponent pozostałościowy wykazywał wysoką lepkość, wysoką zawartość wanadu i siarki oraz dobrą stabilność. Badania paliw z udziałem komponentów biogennych obejmowały analizę w zakresie parametrów typowych dla paliw pozostałościowych oraz stabilności po okresie długotrwałego przechowywania, jak również badania wpływu na elastomery. Uzyskano paliwa o poprawionych właściwościach reologicznych, tj. o znacznie niższej lepkości i temperaturze płynięcia, co umożliwia zmianę warunków przechowywania, dystrybucji i eksploatacji na mniej energochłonne. Paliwa pozostałościowe z udziałem komponentów biogennych w zakresie przebadanych parametrów spełniają wymagania jakościowe dla paliw żeglugowych. Przekroczenie wymagań dla ciężkiego oleju opałowego dotyczących zawartości wanadu wynika z jakości komponentu pozostałościowego. Badane komponenty biogenne nie pogarszają stabilności paliw finalnych nawet w trakcie długotrwałego przechowywania, co jest bardzo istotne w aspekcie warunków eksploatacji tego typu produktów. Wyniki badania wpływu paliw na elastomery wskazują na konieczność wymiany uszczelnień nitrylowych na fluorowe w instalacjach zasilania paliwa.
\end{abstract}

Słowa kluczowe: paliwo pozostałościowe, biowęglowodory, FAME, olej opałowy, paliwo żeglugowe, komponenty biogenne.

\begin{abstract}
In this article, research was carried out on the influence of biogenic components on the quality of residual fuels. The use of biogenic components for composing residual fuels, would allow obtaining marine fuels and heavy fuel oil with improved ecological values, i.e. lower sulfur content and reduced GHG emissions. The research was conducted for one type of heavy fuel base and two light components: FAME and biohydrocarbons from the ETG process. The distillation range of the component from the ETG process was from $172^{\circ} \mathrm{C}$ to approx. $318^{\circ} \mathrm{C}$. It was a stable product of aromatic character, very low pour point and trace sulfur content. The FAME component was characterized by the quality typical for this type of component, with the exception of oxidative stability. The residual component showed high viscosity, high vanadium content, high sulfur content and good stability. The research included analysis of parameters typical for residual fuels and stability during long-term storage as well as the impact of fuels on elastomers. The obtained fuels improved rheological properties, i.e. a much lower viscosity and pour point, which makes it possible to change storage, distribution and exploitation conditions to less energy-consuming ones. Residual fuels with the use of biogenic components, in terms of the parameters tested, meet the quality requirements for marine fuels. Exceeding the requirements for heavy fuel oil in terms of vanadium content results from the quality of the residual component. The biogenic components tested do not deteriorate the stability of final fuels, even during long-term storage, which is very important in terms of the operating conditions of this type of products. Introduction of the tested biogenic components to the composition of residual fuels will involve the need to replace the seals from nitrile to fluorine in the fuel installations.
\end{abstract}

Key words: residual fuel, biohydrocarbons, FAME, fuel oil, marine fuel, biogenic component.

Autor do korespondencji: A. Duda, e-mail: anna.duda@inig.pl

Artykuł nadesłano do Redakcji 13.12.2018 r. Zatwierdzono do druku 16.04.2019 r. 


\section{Wstęp}

Paliwa pozostałościowe wykorzystywane są jako paliwo do kotłów w zakładach energetycznych, jak również do zasilania silników o zapłonie samoczynnym stosowanych w żegludze.

Ostatnio promowanym kierunkiem polityki energetycznej Unii Europejskiej jest zastępowanie paliw kopalnych surowcami biogennymi. Przyjmuje się, że komponenty biogenne mają zerową emisję ditlenku węgla, ponadto charakteryzują się śladową zawartością siarki. Wprowadzenie komponentów lekkich do paliw pozostałościowych wydaje się celowe również ze względu na zmniejszenie lepkości paliwa finalnego, można zatem oczekiwać lepszej atomizacji paliwa, a co za tym idzie - redukcji emisji substancji szkodliwych powstających podczas spalania.

Gama ciekłych biopłynów przeznaczonych do spalania w kotłach przemysłowych obejmuje głównie: surowy olej roślinny, biodiesel, produkty uboczne z produkcji biodiesla oraz bioolej z procesu pirolizy. Stosunkowo niska jakość biooleju oraz wysoki koszt produkcji stanowią duże wyzwanie dla jego powszechnego wykorzystania w dużych zakładach energetycznych (Ushakov et al., 2013). Biodiesel jest głównie przeznaczony do zasilania silników, ale testowany był także jako paliwo do wytwarzania ciepła w kotłach. W publikacjach (Jiru et al., 2010; Bazooyar et al., 2011; Alonso et al., 2012; Daho et al., 2014; González-González et al., 2014) prezentowano wyniki wielu prac przeprowadzonych w obiektach badawczych o małej skali. Dla zastosowań przemysłowych w dużych obiektach energetycznego spalania korzystniejsze jest współspalanie ze względu na ograniczoną dostępność biopłynów oraz minimalizację wpływu na istniejące wyposażenie instalacji (Park et al., 2015, 2017).

Znaczny potencjał paliwowy - pomimo innego składu chemicznego, niższej wartości opałowej, wyższej lepkości i wyższej temperatury zapłonu - ma również powstający w procesie produkcji biodiesla surowy glicerol. Charakteryzuje się on wyższą emisją, wynikającą z obecności katalizatora i tworzenia się toksycznej akroleiny w trakcie spalania (Bohon et al., 2011; Steinmetz et al. 2013). Prowadzono również próby współspalania surowej gliceryny w kotle o mocy 200 MWe przy jej 12-procentowym udziale (Pawlak-Kruczek et al., 2013). Była ona spalana w palnikach olejowych umieszczonych pomiędzy palnikami węglowymi, przez co redukcji uległa emisja tlenków azotu i pyłów.

Badania emisji związków karbonylowych z silnika okrętowego zasilanego paliwem pozostałościowym oraz paliwem destylatowym, zawierającym 3,2\% estrów metylowych oleju rzepakowego, prowadzono na Uniwersytecie w Rostocku (Reda et al., 2015).

W kontekście warunków eksploatacyjnych bardzo ważnym parametrem jest stabilność paliw pozostałościowych (Duda et al., 2017). Warunki eksploatacji paliw pozostałościowych sprzyjają ich szybkiemu starzeniu, przejawiającemu się w wytrącaniu osadów, a tym samym w skłonności do zatykania filtrów w instalacji zasilającej palniki lub silnik. Podobne skutki może wywołać mieszanie paliw pozostałościowych z innymi komponentami.

W Polsce jakość ciężkiego oleju opałowego określa norma PN-C-96024:2011 (Polski Komitet Normalizacyjny, 2011). Jakość paliw żeglugowych określa norma międzynarodowa ISO 8217 (International Organization for Standardization, 2017). Parametry jakościowe paliw żeglugowych zostały szczegółowo opisane w publikacji autorki niniejszego artykułu (Duda, 2014).

\section{Część doświadczalna}

\section{Metody badań}

Komponenty po naważeniu mieszano $\mathrm{w}$ temperaturze $70^{\circ} \mathrm{C}$ przez 20 min z szybkością obrotów mieszadła około $750 \mathrm{rpm}$. Badania próbek paliw obejmowały gęstość, temperaturę zapłonu, lepkość kinematyczną, CCAI, temperaturę płynięcia, zawartość siarki, zawartość osadów obecnych i potencjalnych, zawartość wody, pozostałość po spopieleniu, zawartość wanadu, liczbę kwasową, stabilność metodą plam, kompatybilność z elastomerami, zawartość sodu, zawartość glinu i krzemu, zawartość wapnia i cynku lub wapnia i fosforu, zawartość zanieczyszczeń oraz stabilność oksydacyjną. Metody badań przedstawiono w tabeli 1 .

Tabela 1. Zastosowane metody badań

Table 1. Applied analytical methods

\begin{tabular}{|l|l|l|}
\hline \multicolumn{1}{|c|}{ Badana wlaściwość } & \multicolumn{1}{c|}{ Metoda badawcza } & \multicolumn{1}{c|}{ Aparatura } \\
\hline \hline Lepkość kinematyczna & PN-EN ISO 3104:2004 & łaźnia olejowa z kapilarami Ubbelohdego, Petrotest \\
\hline Gęstość & PN-EN ISO 12185:2002 & gęstościomierz oscylacyjny DMA 4500M, Anton Paar \\
\hline Temperatura płynięcia & PN ISO 3016:2005 & aparat CPP 5Gs, ISL Comp. \\
\hline Zawartość siarki & PN-EN ISO 20884:2012 & aparat Sindie 7039, XOS Comp. \\
\hline $\begin{array}{l}\text { Czystość (kompatybilność) } \\
\text { metodą plam }\end{array}$ & ASTM D 4840:2014 & $\begin{array}{l}\text { płyta grzewcza z mieszadłem magnetycznym RCT Basic IKA-Werke, } \\
\text { suszarka WTB Binder }\end{array}$ \\
\hline
\end{tabular}


cd. Tabela 1 / ect. Table 1

\begin{tabular}{|c|c|c|}
\hline Badana właściwość & Metoda badawcza & Aparatura \\
\hline $\begin{array}{l}\text { Zawartość osadów obecnych i poten- } \\
\text { cjalnych }\end{array}$ & PN ISO 10307:2010 & Setaclean Total Sediment Tester firmy Stanhope-Seta \\
\hline Temperatura zapłonu & PN ISO 2719:2016 & aparat firmy LMM, Hungary, typ OB 305 \\
\hline Liczba kwasowa & PN-88/C-04049 & titrator automatyczny 848 Titrino plus firmy Metrohm, Szwajcaria \\
\hline Pozostałość po koksowaniu & PN EN ISO 10370:2014-12 & $\begin{array}{l}\text { aparat automatyczny NMC } 420 \text { firmy Normalab, Holandia; } \\
\text { waga analityczna AS 310X firmy Radwag, Polska }\end{array}$ \\
\hline Zawartość wody & $\begin{array}{l}\text { PN-83/C-04523/App2:2004; } \\
\text { PN ISO 12937:2005 }\end{array}$ & $\begin{array}{l}\text { aparat Deana-Starka DL } 39 \text {, Mettler Toledo; } \\
\text { aparat do oznaczania zawartości wody firmy Radelkis, typ OP }\end{array}$ \\
\hline Zawartość popiołu & PN-EN ISO 6245:2008 & $\begin{array}{l}\text { piec muflowy WK-106 firmy MOTGOS, Polska } \\
\text { waga analityczna AS 310X firmy Radwag, Polska }\end{array}$ \\
\hline Zawartość wanadu & ASTM D 5708:2015 & \multirow{2}{*}{$\begin{array}{l}\text { spektrometr ICP-OES Spectro Arcos SOP, Spectro Analytical } \\
\text { Instruments }\end{array}$} \\
\hline $\begin{array}{l}\text { Zawartość sodu, glinu, krzemu, cynku, } \\
\text { wapnia, fosforu }\end{array}$ & metodyka ICP-OES & \\
\hline Wartość opałowa & PN-C-04062:1986 & kalorymetr automatyczny KL-10, Precyzja \\
\hline Zawartość zanieczyszczeń & PN EN ISO 3735:2001 & $\begin{array}{l}\text { zestaw do ekstrakcji firmy Normalab, Holandia; } \\
\text { waga analityczna AS 310X firmy Radwag, Polska }\end{array}$ \\
\hline $\begin{array}{l}\text { Stabilność oksydacyjna metodą } \\
\text { przyspieszonego utleniania }\end{array}$ & PN-EN 15751:2014 & aparat 893 Professional Biodiesel Rancimat firmy Metrohm \\
\hline
\end{tabular}

\section{Materiały}

W charakterze surowca pozostałościowego wykorzystywano frakcję ciężką (oznaczoną kodem SG) o właściwościach przedstawionych $\mathrm{w}$ tabeli 2 .

W charakterze komponentów biogennych stosowano:

- frakcję biowęglowodorów aromatycznych (oznaczoną kodem EK) pochodzących z procesu ETG, udostępnioną przez firmę Ekobenz Sp. z o.o.;

\section{- FAME;}

których właściwości także zawarto w tabeli 2.

Komponent z procesu ETG wykazuje typową dla węglowodorów aromatycznych wysoką gęstość przy niskiej lepkości, a zakres destylacji mieści się w przedziale $172-318^{\circ} \mathrm{C}$. Jest produktem stabilnym, o bardzo niskiej temperaturze płynięcia i śladowej zawartości siarki.

Komponent FAME charakteryzuje się jakością typową dla tego typu komponentu z wyjątkiem stabilności oksydacyjnej.

Tabela 2. Właściwości surowców stosowanych w badaniach

Table 2. Properties of raw materials used in tests

\begin{tabular}{|c|c|c|c|}
\hline Wlaściwość & Komponent SG & EK & FAME \\
\hline $\begin{array}{l}\text { Lepkość kinematyczna }\left[\mathrm{mm}^{2} / \mathrm{s}\right] \text { : } \\
\text { - w temperaturze } 50^{\circ} \mathrm{C} \\
\text { - w temperaturze } 20^{\circ} \mathrm{C}\end{array}$ & $\begin{array}{c}976,5 \\
-\end{array}$ & $\begin{array}{c}- \\
1,876\end{array}$ & $\begin{array}{c}- \\
7,302\end{array}$ \\
\hline Gęstość w temperaturze $15^{\circ} \mathrm{C}\left[\mathrm{kg} / \mathrm{m}^{3}\right]$ & 976,2 & 921,8 & 833,4 \\
\hline CCAI & 828 & - & - \\
\hline $\begin{array}{l}\text { Zawartość siarki: } \\
-\%(\mathrm{~m} / \mathrm{m}) \\
-\mathrm{mg} / \mathrm{kg}\end{array}$ & $\begin{array}{c}3,26 \\
-\end{array}$ & - & - \\
\hline Czystość (kompatybilność) metodą plam [stopień] & 1 & - & - \\
\hline Zawartość osadów [\% $(\mathrm{m} / \mathrm{m})]$ & 0,01 & - & - \\
\hline Zawartość osadów potencjalnych [\% $(\mathrm{m} / \mathrm{m})]$ & 0,01 & - & - \\
\hline Temperatura płynięcia $\left[{ }^{\circ} \mathrm{C}\right]$ & -9 & pon. -40 & -12 \\
\hline Wartość opałowa $[\mathrm{kJ} / \mathrm{kg}]$ & 40434 & 40831 & 38706 \\
\hline Liczba kwasowa [mg KOH/g] & 0,45 & $<0,05$ & 0,26 \\
\hline Temperatura zapłonu $\left[{ }^{\circ} \mathrm{C}\right]$ & 71,5 & 63,5 & 149,5 \\
\hline Zawartość wody $[\%(\mathrm{~m} / \mathrm{m})]$ & 0,03 & 0,011 & 0,034 \\
\hline
\end{tabular}


cd. Tabela 2 / ect. Table 2

\begin{tabular}{|c|c|c|c|}
\hline Wlaściwość & Komponent SG & EK & FAME \\
\hline Pozostałość po spopieleniu [\% $(\mathrm{m} / \mathrm{m})]$ & 0,048 & $<0,001$ & $<0,001$ \\
\hline $\begin{array}{l}\text { Zawartość }[\mathrm{mg} / \mathrm{kg}] \text { : } \\
\text { - wanadu } \\
\text { - sodu } \\
\text { - glinu } \\
\text { - krzemu } \\
\text { - wapnia } \\
\text { - cynku } \\
\text { - fosforu }\end{array}$ & $\begin{array}{c}271,0 \\
25,0 \\
4,0 \\
2,0 \\
3,3 \\
1,8 \\
0\end{array}$ & $\begin{array}{c}0 \\
0 \\
0 \\
28 \\
0 \\
0 \\
0\end{array}$ & $\begin{array}{c}0 \\
0 \\
0 \\
0,5 \\
0 \\
5 \\
0\end{array}$ \\
\hline $\begin{array}{l}\text { Skład frakcyjny: } \\
\text { - koniec destylacji }\left[{ }^{\circ} \mathrm{C}\right] \\
\text { - do } 250^{\circ} \mathrm{C} \text { przedestylowało }[\%(V / V)] \\
\text { - do } 350^{\circ} \mathrm{C} \text { przedestylowało }[\%(V / V)]\end{array}$ & $\begin{array}{l}- \\
- \\
-\end{array}$ & $\begin{array}{r}318,6 \\
78,4 \\
99,1\end{array}$ & $\begin{array}{l}- \\
- \\
-\end{array}$ \\
\hline Odporność na utlenianie $\left[\mathrm{g} / \mathrm{m}^{3}\right]$ & - & 3 & - \\
\hline Stabilność oksydacyjna metodą przyspieszonego utleniania [h] & - & - & 6,9 \\
\hline \multicolumn{4}{|l|}{ Wyniki badań po starzeniu w temperaturze $80^{\circ} \mathrm{C}$ w ciągu 1 miesiąca } \\
\hline Czystość (kompatybilność) metodą plam [stopień] & 1 & - & - \\
\hline Zawartość osadów [\% $(\mathrm{m} / \mathrm{m})]$ & 0,02 & - & - \\
\hline
\end{tabular}

\section{Wyniki badań}

Skład i właściwości wytworzonych próbek paliw przedstawiono w tabeli 3.

Najbardziej widoczny wpływ badanych komponentów biogennych zaobserwowano w zakresie lepkości. Lepkość kinematyczna pozostałościowego paliwa bazowego, wynosząca $976,5 \mathrm{~mm}^{2} / \mathrm{s}$, została obniżona ponad dwudziestokrotnie po dodaniu biowęglowodorów z procesu ETG w stężeniu 30\% $(\mathrm{m} / \mathrm{m})$ oraz ok. piętnastokrotnie po dodaniu 30\% $(\mathrm{m} / \mathrm{m})$ FAME. Jednocześnie zmianom lepkości towarzyszył niewielki spadek

Tabela 3. Wyniki badań skomponowanych paliw

Table 3. Test results of composed fuels

\begin{tabular}{|c|c|c|c|c|c|c|}
\hline Kod próbki/udział komponentu [\% $(\mathrm{m} / \mathrm{m})]$ & 10ES & 20ES & 30ES & 10FS & 20FS & 30FS \\
\hline Komponent biogenny EK & 10 & 20 & 30 & 0 & 0 & 0 \\
\hline Komponent biogenny FAME & 0 & 0 & 0 & 10 & 20 & 30 \\
\hline Komponent pozostałościowy SG & 90 & 80 & 70 & 90 & 80 & 70 \\
\hline \multicolumn{7}{|l|}{ Właściwości: } \\
\hline Lepkość w temperaturze $50^{\circ} \mathrm{C}\left[\mathrm{mm}^{2} / \mathrm{s}\right]$ & 266,5 & 90,22 & 35,32 & 365,6 & 137,2 & 62,60 \\
\hline Lepkość w temperaturze $100^{\circ} \mathrm{C}\left[\mathrm{mm}^{2} / \mathrm{s}\right]$ & 30,8 & 15,1 & 9,3 & 35,5 & 21,9 & 16,4 \\
\hline Gęstość w temperaturze $15^{\circ} \mathrm{C}\left[\mathrm{kg} / \mathrm{m}^{3}\right]$ & 971,2 & 965,5 & 959,6 & 968,0 & 957,5 & 947,3 \\
\hline CCAI & 836 & 843 & 851 & 829 & 830 & 830 \\
\hline Zawartość siarki & 2,93 & 2,61 & 2,28 & 2,93 & 2,61 & 2,28 \\
\hline Zawartość zanieczyszczeń [\% $(\mathrm{m} / \mathrm{m})]$ & 0,04 & 0,04 & 0,04 & 0,05 & 0,05 & 0,05 \\
\hline Czystość (kompatybilność) metodą plam [stopień] & 1 & 1 & 1 & 1 & 1 & 1 \\
\hline Zawartość osadów [\% $(\mathrm{m} / \mathrm{m})]$ & 0,00 & 0,01 & 0,01 & 0,01 & 0,01 & 0,01 \\
\hline Zawartość osadów potencjalnych $[\%(\mathrm{~m} / \mathrm{m})]$ & 0,01 & 0,01 & 0,01 & 0,01 & 0,01 & 0,01 \\
\hline Temperatura płynięcia $\left[{ }^{\circ} \mathrm{C}\right]$ & -24 & -30 & -38 & -15 & -24 & -27 \\
\hline Wartość opałowa $[\mathrm{kJ} / \mathrm{kg}]$ & 40474 & 40513 & 40553 & 40261 & 40088 & 39916 \\
\hline Liczba kwasowa [mg KOH/g] & 0,46 & 0,42 & 0,39 & 0,26 & 0,25 & 0,24 \\
\hline Pozostałość po koksowaniu [\% $(\mathrm{m} / \mathrm{m})]$ & 17,76 & 15,77 & 13,78 & 15,02 & 14,42 & 13,81 \\
\hline Temperatura zapłonu $\left[{ }^{\circ} \mathrm{C}\right]$ & 70,5 & 68,5 & 66,5 & 82,0 & 84,0 & 85,0 \\
\hline
\end{tabular}


cd. Tabela 3/ ect. Table 3

\begin{tabular}{|c|c|c|c|c|c|c|}
\hline Kod próbki/udział komponentu [\% $(m / m)]$ & 10ES & 20ES & 30ES & 10FS & 20FS & 30FS \\
\hline Zawartość wody $[\%(\mathrm{~m} / \mathrm{m})]$ & 0,03 & 0,03 & 0,02 & 0,03 & 0,03 & 0,03 \\
\hline Pozostałość po spopieleniu $[\%(\mathrm{~m} / \mathrm{m})]$ & 0,043 & 0,039 & 0,034 & 0,043 & 0,039 & 0,034 \\
\hline $\begin{array}{l}\text { Zawartość }[\mathrm{mg} / \mathrm{kg}]: \\
\text { - wanadu } \\
\text { - sodu } \\
\text { - glinu } \\
\text { - krzemu } \\
\text { - wapnia } \\
\text { - cynku } \\
\text { - fosforu }\end{array}$ & $\begin{array}{c}244 \\
22,5 \\
3,6 \\
4,6 \\
2,97 \\
1,6 \\
0\end{array}$ & $\begin{array}{c}217 \\
20 \\
3,2 \\
7,2 \\
2,6 \\
1,4 \\
0\end{array}$ & $\begin{array}{c}190 \\
17,5 \\
2,8 \\
9,8 \\
2,3 \\
1,3 \\
0\end{array}$ & $\begin{array}{c}244 \\
22,5 \\
3,6 \\
1,9 \\
3,0 \\
1,6 \\
0\end{array}$ & $\begin{array}{c}217 \\
20 \\
3,2 \\
1,7 \\
2,6 \\
1,4 \\
0 \\
\end{array}$ & $\begin{array}{c}190 \\
17,5 \\
2,8 \\
1,6 \\
2,3 \\
1,3 \\
0\end{array}$ \\
\hline Kategoria ISO-F- & RMG 380 & RMG 180 & RMG 180 & RMG 380 & RMG 180 & RMG 180 \\
\hline \multicolumn{7}{|c|}{ Wyniki badań po starzeniu w temperaturze $80^{\circ} \mathrm{C}$ w ciągu 1 miesiąca } \\
\hline Czystość (kompatybilność) metodą plam [stopień] & 1 & 1 & 1 & 1 & 1 & 1 \\
\hline Zawartość osadów [\% $(\mathrm{m} / \mathrm{m})]$ & 0,01 & 0,01 & 0,01 & 0,01 & 0,01 & 0,02 \\
\hline
\end{tabular}

gęstości oraz - w przypadku paliw zawierających biowęglowodory z procesu BTL - nieznaczny wzrost indeksu CCAI. Wzrost CCAI nie jest zjawiskiem korzystnym, świadczy o pogorszeniu właściwości zapłonowych, niemniej jednak to zjawisko typowe dla węglowodorów o charakterze aromatycznym. Wpływ dodatku biokomponentów na wybrane parametry przedstawiono na rysunku 1 .

Dla paliw z udziałem FAME nieoczekiwanie osiągnięto stosunkowo niskie temperatury płynięcia, znacznie niższe niż wartości tego parametru dla komponentów wchodzących w ich skład. Można przypuszczać, że obniżenie temperatury płynięcia wynika z nietypowych zmian lepkości mieszaniny w niskich temperaturach. Według Maksimuka i wsp. (2013) zjawisko takie może wynikać z ograniczonej rozpuszczalności FAME we frakcjach ciężkich, co w konsekwencji prowadzi

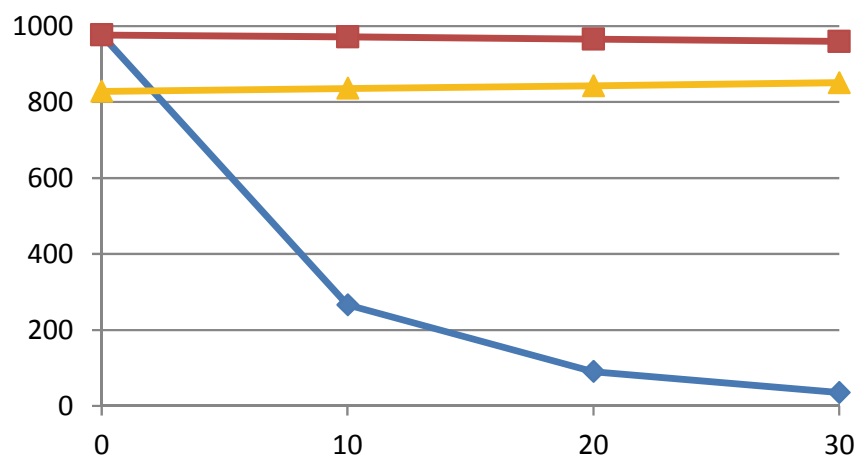

Zawartość biowęglowoodorów [\% $(\mathrm{m} / \mathrm{m})]$

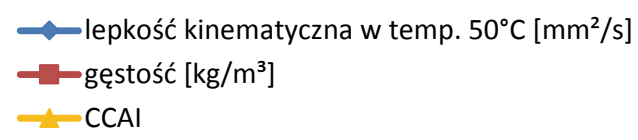

Rys. 1. Wpływ biowęglowodorów z procesu BTL na wybrane parametry jakościowe paliw pozostałościowych

Fig. 1. Impact of biohydrocarbons from the BTL process on selected quality parameters of residual fuels do częściowej separacji obu faz i zmniejszenia oporu przepływu warstw paliwa.

Ze względu na wpływ badanych komponentów biogennych na właściwości reologiczne paliw pozostałościowych należy oczekiwać istotnych zmian w warunkach ich przechowywania, dystrybucji i eksploatacji.

Obecność komponentów biogennych, tj. FAME i biowęglowodorów z procesu ETG, w paliwach pozostałościowych spowodowała ponadto znaczne obniżenie zawartości siarki w paliwach finalnych: z 3,26\% $(\mathrm{m} / \mathrm{m})$ w paliwie bazowym do $2,28 \%(\mathrm{~m} / \mathrm{m})$ w paliwach zawierających $30 \%(\mathrm{~m} / \mathrm{m})$ biokomponentu. Należy przypuszczać, że zarówno zmiany lepkości, jak i zawartości siarki w paliwach pozostałościowych z udziałem komponentów biogennych będą miały istotny wpływ na redukcję emisji substancji szkodliwych powstających podczas spalania.

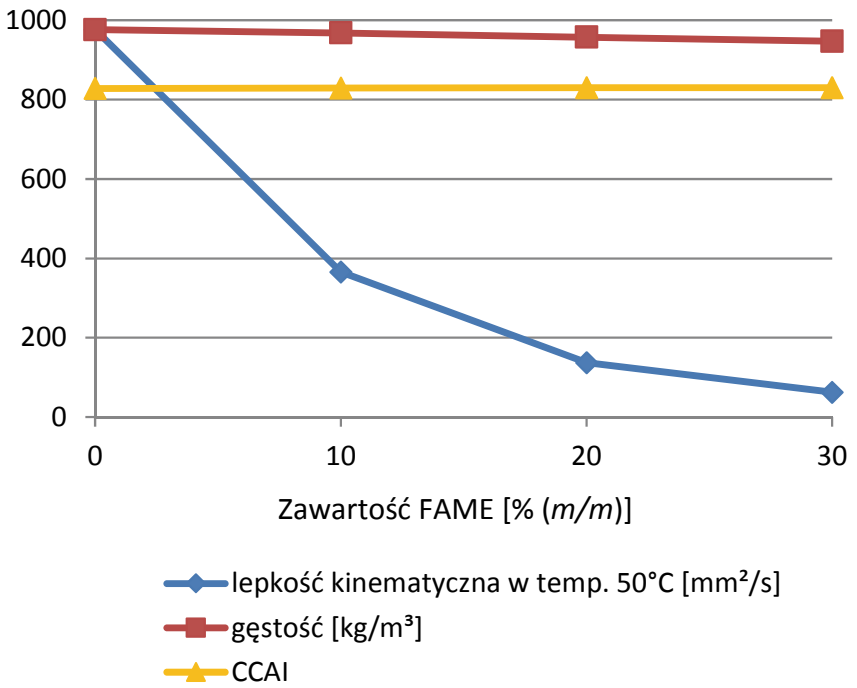

Rys. 2. Wpływ FAME na wybrane parametry jakościowe paliw pozostałościowych

Fig. 2. Impact of FAME on selected quality parameters of residual fuels 
Zaobserwowano również wyraźny spadek pozostałości po koksowaniu wraz ze wzrostem zawartości biokomponentów: od wartości $19,52 \%(\mathrm{~m} / \mathrm{m})$ dla paliwa pozostałościowego bazowego do około $14 \%(\mathrm{~m} / \mathrm{m})$ dla paliw zawierających $30 \%(\mathrm{~m} / \mathrm{m})$ biokomponentu.

Paliwa z badanymi biokomponentami charakteryzują się dobrą stabilnością w trakcie długotrwałego przechowywania: czystość (kompatybilność) oznaczona według ASTM D 4740 wynosi 1 , tj. przyjmuje wartość typową dla paliw stabilnych, a zawartość osadów wynosi $0,01 \%(\mathrm{~m} / \mathrm{m})$ i nie ulega zmianie po okresie długotrwałego przechowywania.

Paliwa z komponentem EK w ilości 10\% $(\mathrm{m} / \mathrm{m})$ spełniają wymagania normy ISO 8217 dla paliw żeglugowych kategorii RMG 380, natomiast paliwa o zawartości biowęglowodorów wynoszącej $20 \%(\mathrm{~m} / \mathrm{m})$ i $30 \%(\mathrm{~m} / \mathrm{m})$ - wymagania dla kategorii RMG 180. W przypadku paliw z udziałem $20 \%$ i $30 \%(\mathrm{~m} / \mathrm{m})$ biowęglowodorów stwierdzono nietypową korelację pomiędzy lepkością a zawartością wanadu.

Paliwo zawierające $10 \%(\mathrm{~m} / \mathrm{m})$ FAME w zakresie przebadanych parametrów spełnia wymagania jakościowe zawarte w tabeli 2 normy ISO 8217 dla kategorii RMG 380, a paliwa z udziałem $20 \%(\mathrm{~m} / \mathrm{m})$ i $30 \%(\mathrm{~m} / \mathrm{m})$ FAME - dla kategorii RMG 180. Paliwo zawierające $30 \%(\mathrm{~m} / \mathrm{m})$ FAME charakteryzuje się nietypowo wysoką zawartością wanadu przy stosunkowo niskiej lepkości. Pomimo że paliwa spełniają wymagania jakościowe zawarte w tabeli 2 normy ISO 8217, należy zaznaczyć, że aktualnie norma ta dopuszcza stosowanie FAME jedynie w paliwach destylatowych.

Żadne ze skomponowanych paliw nie spełnia wymagań normy PN-C-96024:2011 dla olejów opałowych w zakresie zawartości wanadu (dopuszczalna zawartość wanadu nie powinna przekraczać $150 \mathrm{mg} / \mathrm{kg}$ ), co nie wynika z obecności komponentów biogennych, lecz z jakości komponentu ciężkiego.

Przeprowadzono również badania wpływu komponentów biogennych na kompatybilność paliw finalnych z elastomerami: elastomerem nitrylowym NBR 28 oraz elastomerem fluorowym FPM. Badania prowadzono porównawczo dla bazowego paliwa pozostałościowego. Wyniki badań przedstawiono w tabeli 4.

Przedstawione dane wskazują, że komponent o charakterze aromatycznym, tj. pochodzący z procesu ETG, ma istotny wpływ na kompatybilność paliw finalnych z elastomerem
NBR 28: zmiana objętości elastomeru jest około 2,5-krotnie większa niż dla paliwa bazowego. Stwierdzono również duży wpływ komponentu FAME na zmianę wytrzymałości elastomeru - jest ona około 2,6-krotnie większa w przypadku paliwa z udziałem $30 \%(\mathrm{~m} / \mathrm{m})$ FAME niż paliwa pozostałościowego SG niezawierającego tego komponentu.

W teście $\mathrm{z}$ elastomerem FPM zmiany objętości elastomeru dla paliwa z udziałem $30 \%(\mathrm{~m} / \mathrm{m})$ biowęglowodorów są znacznie mniejsze i wynoszą 3,95\%. Zmiany badanych parametrów, tj. wytrzymałości, wydłużenia, twardości i objętości elastomeru, w teście prowadzonym dla paliw zawierających FAME są nieznaczne.

Tabela 4. Wpływ badanych komponentów biogennych na kompatybilność paliw z elastomerami Table 4. Impact of biogenic components on the fuels' compatibility with elastomers

\begin{tabular}{|c|c|c|c|}
\hline Próbka & SG & $30 \mathrm{ES}$ & 30 FS \\
\hline $\begin{array}{l}\text { Warunki badania: } \\
\text { - czas: } 168 \mathrm{~h} \\
\text { - temperatura } 80^{\circ} \mathrm{C}\end{array}$ & \multicolumn{3}{|c|}{ elastomer nitrylowy NBR 28} \\
\hline Zmiana wytrzymałości [\%] & $-6,68$ & $-7,34$ & $-17,41$ \\
\hline Zmiana wydłużenia [\%] & 10,41 & 10,77 & 13,89 \\
\hline Zmiana twardości [IRHD] & $-12,1$ & $-18,7$ & $-10,5$ \\
\hline Zmiana objętości [\%] & 14,44 & 36,78 & 20,32 \\
\hline $\begin{array}{l}\text { Warunki badania: } \\
\text { - czas: } 168 \mathrm{~h} \\
\text { - temperatura } 80^{\circ} \mathrm{C}\end{array}$ & \multicolumn{3}{|c|}{ elastomer fluorowy FPM } \\
\hline Zmiana wytrzymałości [\%] & $-7,68$ & $-11,23$ & $-3,20$ \\
\hline Zmiana wydłużenia [\%] & 12,07 & 5,38 & 2,67 \\
\hline Zmiana twardości [IRHD] & $-2,1$ & $-0,1$ & 0,4 \\
\hline Zmiana objętości [\%] & 0,96 & 3,95 & 0,29 \\
\hline
\end{tabular}

Podsumowanie

Wykorzystanie komponentów biogennych, tj. biowęglowodorów aromatycznych z procesu ETG oraz FAME, do komponowania paliw pozostałościowych stanowi obiecującą perspektywę poprawy parametrów jakościowych i eksploatacyjnych paliw opałowych i żeglugowych. Zastosowanie komponentów biogennych spowodowało bardzo znaczące obniżenie lepkości paliw pozostałościowych z ich udziałem. Dla paliw z FAME uzyskano ponadto stosunkowo niskie temperatury płynięcia, znacznie niższe niż wartości tego parametru dla komponentów wchodzących w ich skład. Ze względu na korzystny wpływ badanych biokomponentów na właściwości reologiczne paliw pozostałościowych można spodziewać się istotnych zmian w warunkach ich przechowywania, dystrybucji i eksploatacji na mniej energochłonne.

Dodatkową zaletą komponentów biogennych jest śladowa zawartość siarki, co poprawia walory ekologiczne paliw zestawionych z ich udziałem. 
Badane komponenty biogenne nie pogarszają stabilności paliw finalnych nawet w trakcie długotrwałego przechowywania, co jest bardzo istotne w aspekcie warunków eksploatacji tego typu produktów.

Badane komponenty biogenne wykazują jednak niekorzystne działanie na elastomery nitrylowe, co wskazuje na konieczność wymiany uszczelnień na fluorowe w instalacjach zasilania.

Artykuł powstał na podstawie pracy statutowej pt. Ocena możliwości zastosowania komponentów odpadowych i biogennych $w$ paliwach pozostałościowych - praca INiG - PIB na zlecenie MNiSW; nr zlecenia: TP/76/2018, nr archiwalny: DK-4100-76/1.

\section{Literatura}

Bazooyar B., Ghorbani A., Shariati A., 2011. Combustion performance and emissions of petrodiesel and biodiesels based on various vegetable oils in a semi industrial boiler. Fuel, 90: 3078-3092. DOI: 10.1016/j.fuel.2011.05.025.

Bohon M.D., Metzger B.A., Linak W.P., King C.J., Roberts W.L., 2011. Glycerol combustion and emissions. Proc. Combust. Inst., 33(2): 2717-2724. DOI: 10.1016/j.proci.2010.06.154.

Daho T., Vaitilingom G., Sanogo O., Ouiminga S.K., Zongo A.S., Piriou B., Koulidiati J., 2014. Combustion of vegetable oils under optimized conditions of atomization and granulometry in a modified fuel oil burner. Fuel, 118: 329-334. DOI: 10.1016/j. fuel.2013.11.009.

Duda A., 2014. Prawne i jakościowe aspekty stosowania paliw żeglugowych. Nafta-Gaz, 12: 968-973.

Duda A., Berdechowski K., Żak G., 2017. Wpływ pakietu dodatków na właściwości paliwa pozostałościowego w trakcie przechowywania. Nafta-Gaz, 2: 105-108. DOI: 10.18668/NG.2017.02.05.

González-González J.F., Alkassir A., San José J., González J., GómezLandero A., 2014. Study of combustion process of biodiesel/ gasoil mixture in a domestic heating boiler of $26.7 \mathrm{~kW}$. Biomass Bioenergy, 60: 178-188. DOI: 10.1016/j.biombioe.2013.10.024.

Jiru T.E., Kaufman B.G., Ileleji K.E., Ess D.R., Gibson H.G., Maier D.E., 2010. Testing the performance and compatibility of degummed soybean heating oil blends for use in residential furnaces. Fuel, 89: 105-113. DOI: 10.1016/j.fuel.2009.07.028.

Maksimuk Y., Buglak A.F., Kruk V.S., Antonova Z.A., 2013. Rheological properties of residual fuel oil containing fuel blends with bioadditives. Part 2. Bioadditives based on methyl esters of rapeseed oil. Chemistry and Technology of Fuels and Oils, 49(2): 108-114. DOI: 10.1007/s10553-013-0420-1.
Park J.-K., Park S., Kim M., Ryu C., Baek S.H., Kim Y.J., Kim H.H., Park H.Y., 2015. CFD analysis of combustion characteristics for fuel switching to bioliquid in oil-fired power plant. Fuel, 159: 324-333. DOI: 10.1016/j.fuel.2015.06.079.

Park J.-K., Park S., Ryu C., Baek S.H., Kim Y.J., Park H.Y., 2017. CFD analysis on bioliquid co-firing with heavy fuel oil in a $400 \mathrm{MWe}$ power plant with a wall-firing boiler. Applied Thermal Engineering, 124: 1247-1256. DOI: 10.1016/j.applthermaleng.2017.06.104.

Pawlak-Kruczek H., Ostrycharczyk M., Zgóra J., 2013. Cocombustion of liquid biofuels in PC boilers of 200 MW utility unit. Proc. Combust. Inst., 34(2): 2769-2777. DOI: 10.1016/j. proci.2012.08.010.

Reda A.A., Schnelle-Kreis J., Orasche J., Abbaszade G., Lintelmann J., Arteaga-Salas J.M., Stengel B., Rabe R., Harndorf H., Sippula O., Streibel T., Zimmermann R., 2015. Gas phase carbonyl compounds in ship emissions: Differences between diesel fuel and heavy fuel oil operation, Atmospheric Environment, 112: 370-380, DOI: 10.1016/j.atmosenv.2015.03.057.

San José Alonso J.F., Romero-Ávila C., San José Hernández L.M., Al-Kassir Awf., 2012. Characterising biofuels and selecting the most appropriate burner for their combustion. Fuel Process Technol., 103: 39-44. DOI: 10.1016/j.fuproc.2011.07.023.

Steinmetz S.A., Herrington J.S., Winterrowd C.K., Roberts W.L., Wendt J.O.L., Linak W.P., 2013. Crude glycerol combustion: particulate, acrolein, and other volatile organic emissions. Proc. Combust. Inst., 34(2): 2749-2757. DOI: 10.1016/j. proci.2012.07.050.

Ushakov S., Valland H., Nielsen J.B., Hennie E., 2013. Effects of high sulphur content in marine fuels on particulate matter emission characteristics. J. Mar. Eng. Technol., 12: 30-39.

\section{Akty normatywne}

International Organization for Standardization, 2017. Petroleum products - Fuels (class F) - Specifications of marine fuels. ISO 8217:2017.

Polski Komitet Normalizacyjny, 2011. Przetwory naftowe. Oleje opałowe. PN-C-96024:2011.

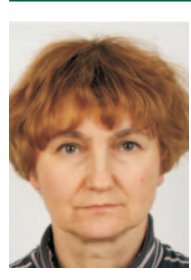

Mgr inż. Anna DUDA

Specjalista badawczo-techniczny w Zakładzie Paliw i Procesów Katalitycznych

Instytut Nafty i Gazu - Państwowy Instytut Badawczy ul. Lubicz 25 A

31-503 Kraków

E-mail:anna.duda@inig.pl 